\title{
Short Communication: New distributional record of Phyllanthus securinegoides Merr. (Phyllanthaceae) and Rinorea niccolifera Fernando (Violaceae) of Homonhon Island, Philippines
}

\author{
ROANNE B. ROMEROSO ${ }^{1,2, \boldsymbol{v}}$, DANILO N. TANDANG ${ }^{3}$, IAN A. NAVARRETE ${ }^{4}$ \\ ${ }^{1}$ Department of Biology, College of Science, University of Eastern Philippines, Catarman, 6400 Northern Samar, Philippines, \\ vemail: romerosoroanne.uep@gmail.com \\ ${ }^{2}$ The Graduate School and Research Center for the Natural and Applied Sciences, University of Santo Tomas. España Boulevard, 1015 Manila, \\ Philippines \\ ${ }^{3}$ Division of Botany, National Museum of the Philippines. Padre Burgos Av., Ermita, 1000 Metro Manila, Philippines \\ ${ }^{4}$ Department of Environmental Science, Southern Leyte State University. Hinunangan Campus, Ambacon, Hinunangan, 6608 Southern Leyte, Philippines
}

Manuscript received: 30 October 2020. Revision accepted: 31 December 2020.

\begin{abstract}
Romeroso RB, Tandang DN, Navarrete IA. 2021. Short Communication: New distributional record of Phyllanthus securinegoides Merr. (Phyllanthaceae) and Rinorea niccolifera Fernando (Violaceae) of Homonhon Island, Philippines. Biodiversitas 22: 499-503. Homonhon Island is an ultramafic forest island located on the east coast of Guiuan, Eastern Samar, Philippines. Due to the naturally rich deposit of $\mathrm{Ni}$ and $\mathrm{Cr}$ ore, the island is affected by mining activities where metallophytes thrive. These metallophytes have the potential to use in mining industries for ecological restoration. However, metallophytes are least documented in the Philippines. Phyllanthus securinegoides Merr. and Rinorea niccolifera Fernando is some of the metallophytes mostly documented in Surigao, Palawan, and Zambales, Philippines, but are not yet recorded in Samar. Moreover, these metallophytes are considered as new distribution records of metallophytes in the Philippines island. These plant resources must be conserved due to their physiological uniqueness. The study provides photographs and other relevant information of the collected species to compare the previous and present collections based on the previous and available literature.
\end{abstract}

Keywords: Biodiversity, metallophytes, metal-accumulator, mining, phytoremediation, Phyllanthaceae, Samar, Violaceae

\section{INTRODUCTION}

The Philippine archipelago has a land area of 300,000 $\mathrm{km}^{2}$ or 30 million hectares and is composed of 7,641 islands (Amoroso 2012). Islands are important sources of information for conserving plant diversity, because nearly all vascular plants are endemic (Castells et al. 2010). The plants that are confined in the islands are unique because they are isolated and-have undergone different evolutionary processes (Gillespie 2007). Although the Philippines has a small land area, it braced thousands of habitats that support endemic species. According to Brown et al (2013), the Philippines is considered one of the mega-diverse countries in the world. One-third of the more than 9,250 vascular plant species are native to the Philippines (Brown et al. 2013).

Homonhon Island is located in the eastern part of Samar, Philippines. The island is one of the unexplored islands in the Philippine archipelago in terms of botanical expedition (Abulencia 2013). The island is rich in natural resources that include $\mathrm{Ni}, \mathrm{Cr}$, and $\mathrm{Co}$, which resulted to attract mining companies to operate in the area since 1980s (Abulencia 2013). The mining activities have altered the ecosystem in the area that destroys the habitats of the metallophytes (Kicinska and Kosowska 2016). Metallophytes are plants grown naturally on metal-rich soils. They are able to accumulate heavy metal in their biomass with no adverse effect on their physiological processes or without showing phytotoxicity (Baker and Brooks 1989). While metallophytes are used as indicator of heavy metals in polluted soils, many of the metallophyte species are least explored in the Philippines (Aribal et al 2016). Phyllanthus securinegoides Merr. and Rinorea niccolifera Fernando is some of the metallophytes documented in the Philippines mostly in Luzon Island and Mindanao Island (Fernando 2014; Quimado et al. 2015).

Phyllanthus securinegoides Merr, and Rinorea niccolifera Fernando are only some of the metallophytes documented in Luzon and Mindanao Islands in the Philippines.

\section{MATERIALS AND METHODS}

\section{Study area}

Homonhon Island is part of the municipality of Guiuan, Eastern Samar located on the east side of Leyte Gulf and situated $10^{\circ} 44^{\prime} 30^{\prime \prime}$ North and 125 43'19" East (Figure 1). It has a total area of 7,400 ha, with a population of 7,000 (Abulencia 2013). The island is composed of eight barangays: Casuguran, Inapulangan, Habag, Canuwayon, Bitaugan, Culasi, Pagbabangnan, and Cagusuan. The 
elevation of the ultramafic forest in Homonhon Island ranges from 26 to $271 \mathrm{~m}$ a.s.l. $\left(10^{\circ} 48^{\prime} 24.1 \mathrm{~N}\right.$; $\left.125^{\circ} 44^{\prime} 29.7 \mathrm{E}\right)$. Based on Coronas (1920), the islands' climate is classified under the Type II climate with no dry season but with a very pronounced maximum rainfall from November to January. The northeast monsoon prevails during the rainy months of November to January while the westerly winds prevail during the months of February to October with less rainfall. Mining activities in the island have started during the 1980 s owing to the abundance of heavy metals, specifically chromium and nickel (Abulencia 2013). Until now, on the island mining activities are sustained. These may affect the well-being of the people living in the community as well as result in biodiversity loss. We conducted plant survey on five barangays in Homonhon Island, namely, Habag, Casuguran, Culasi, Bitaugan and Pagbabangnan. Random sampling through the lottery method (Chafjiri et al. 2016) was done with the selection of sampling areas. Sampling was done using 2$\mathrm{km}$ transect to establish the $10 \times 10 \mathrm{~m}$ quadrat (Replan and Malaki 2017), 20 quadrats were made per sampling area. A total of 100 quadrats of $10 \times 10 \mathrm{~m}$ was established with 100 $\mathrm{m}$ intervals to document the metallophytes of Homonhon Island.

\section{The survey, collection, processing of specimens, and specimen identification}

To satisfy the RA 9147 (Wildlife Resources Conservation and Protection Act) legal requirement prior informed consent secured from the Mayor's Office of Guiuan, Eastern Samar, and submitted research proposal to the Department of Environment and Natural ResourcesTacloban City of Region 8 to obtain Gratuitous Permit No. R08-37 for us to perform the study on Homonhon Island. The floristic study was performed in October 2016. Random sampling through the lottery method (Chafjiri et al. 2016) was done with the selection of sampling areas. Three sets of voucher specimens were collected. Plant specimens were processed for herbarium preparation and placed vouchers at the University of Santo Tomas Herbarium (USTH). The collections were then identified utilizing taxonomic keys and species descriptions, and/or using available online resources such as thephilippineplants.org (Pielser et al. 2011) or types from virtual herbaria for image comparisons and authenticated by the National Museum of the Philippines.

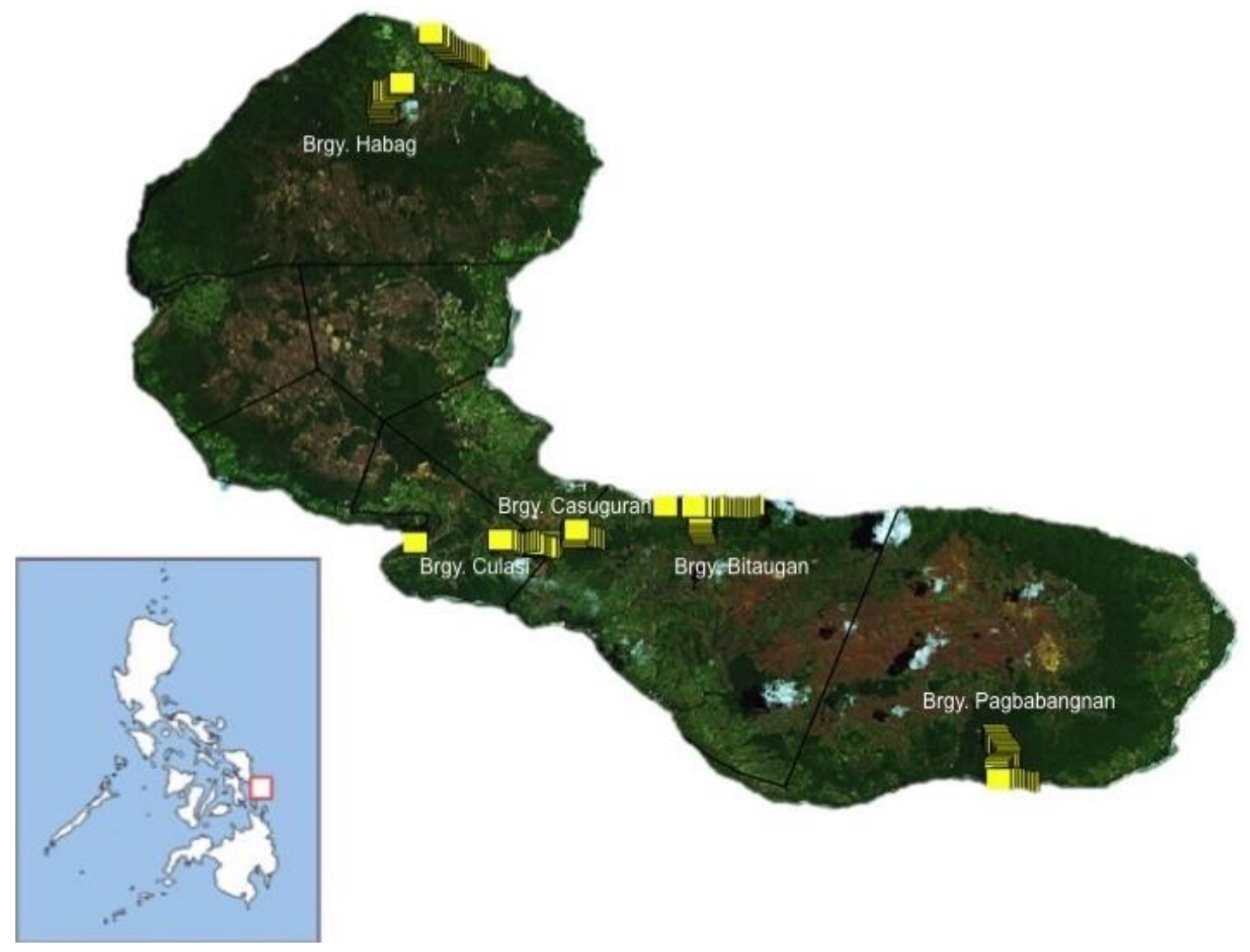

Figure 1. Map of Homonhon Island, Guiuan, Eastern Samar, Philippines. Areas surveyed are marked with a yellow square (Brgy. Habag, Brgy. Casuguran, Brgy. Culasi, Brgy. Bitaugan, and Brgy. Pagbabangnan) 


\section{RESULTS AND DISCUSSION}

The two metallophytes are Rinorea niccolifera Fernando and Phyllanthus securinegoides Merr., which are often seen and documented in the islands of Luzon and Mindanao (Merrill 1912; Fernando et al. 2013, 2014; Quimado et al. 2015; Ata et al. 2016) (Table 1). Our study revealed a new distributional record of metallophyte species found in the barangays of Casuguran and Habag, of Homonhon Island, Philippines. Photographs, taxonomic description and authentication from a botanist, verified that Phyllanthus securinegoides and Rinorea niccolifera are now recorded for the first time on Homonhon Island, one of the underexplored ultramafic forests in the Philippines. This can also be considered new knowledge on the distribution of metallophytes in Visayas Island. The presence of these metallophytes in the area has potential implications in the ecological restoration of heavy metalcontaminated areas as well as for policy-making conservation of these native metallophytes for phytoremediation. This suggests conservation of these species that can be used to restore areas that have been affected by mining, particularly in Homonhon Island. Moreover, metallophytes are widespread throughout the world, which has an integral part of the biodiversity particularly in metalliferous soils (Whiting 2004). More species of metallophytes remain to be discovered in the area, which warrants more studies on this aspect in the area. Concerted efforts must be done to conserve all metallophyte species, integrating the efforts of scientists, industry, and governments. The primary mechanism for ensuring the survival of metallophytes in mined areas is to promote their use in ecological restoration and site rehabilitation at mine closure. Moreover, constant effort must be made in the ultramafic areas to record the distribution of these species since these species are one-tool for greener environment.

\section{Description of specimens}

Here, we present the description of the metallophytes collected in Homonhon Island.
Phyllanthus securinegoides, Merr. sp.nov.

A shrub, height is 4 to $5 \mathrm{~m}$, branches- stem is brownish and pale green, with 8 leaves attached in the branches usually in equal number, leaf shape is elliptic-lanceolate, leaf arrangement is alternate. Flowers are white or cream, the axillary fascicles in female are more numerous than male. Male pedicel is tiny, brown and usually stiff upward, perianth $2 \mathrm{~mm}$ long, the lobes of the pedicel are not equally shaped usually oblong-elliptic-obovate. The stamen is 3, the filaments 1 to $2 \mathrm{~mm}$ long. The female pedicels are elongated, the lobes of the perianth are ovate-obtuse. The ovary is glabrous, the styles are lying flat to the ovary, and usually merged at the base to form a forked shape. The shape of the fruit globe-like.

This species thrives in ultramafic forests, at elevations of 185 to $220 \mathrm{~m}$; these are widely distributed in the ultramafic forests of Luzon Island, Province of Tayabas, Municipality of Guinayangan and Guinacatacutan, Mindanao Island, Province of Surigao del Norte, Municipality of Claver.

\section{Rinorea niccolifera Fernando sp.nov.}

A shrub's height is 2 to $8 \mathrm{~m}$ and has smooth, brown outer bark. The leaf venation is simple, margin is serrated, base is acute and acuminate apex; the domatia in the midrib are hairy and prominent on the abaxial surface of the leaf, the petiole is circular to columnar without ridge, the young leaves are greenish-white. The stipules are straight, long to narrow in base. The flowers are cream in color, the stalk is usually with fine short hairs. The sepals are considered not equal in size and shape, mostly wide and long broadly ovate, shade is light green to greenish-white, the apex is thin, hairy, and brown. The petal's shape is broadly ovate, the apex is obtuse with white to greenish-white color, usually becoming paler towards the edge. The shape of the fruit is capsule globose-like, usually green to pale green especially when ripe.

This species grows in forests on ultramafic-derived soils, at elevations of 131 to $184 \mathrm{~m}$. This is widely distributed in Luzon Island, Zambales Province, Municipalities of Sta. Cruz and Candelaria.

Table 1. Rinorea niccolifera and Phyllanthus securinegoides their collected location in the Philippines islands

\begin{tabular}{lll}
\hline \multicolumn{1}{c}{ Metallophytes } & \multicolumn{1}{c}{ Location } & \multicolumn{1}{c}{ References } \\
\hline Phyllanthus securinegoides Merr. & Tayabas Province on Luzon Island & Merrill (1912) \\
Rinorea niccolifera Fernando. & Zambales Province on Luzon Island & Fernando (2014) \\
Phyllanthus securenigoides Merr. & Surigao del Norte on Mindanao Island & Quimado et al. (2015) \\
Phyllanthus securenigoides Merr. & Surigao del Norte on Mindanao Island & Ata et al. (2016) \\
Rinorea niccolifera Fernando & Guiuan E. Samar on Visayas Island & This study \\
Phyllanthus securinegoides Merr. & Guiuan E. Samar on Visayas Island & This study \\
\hline
\end{tabular}




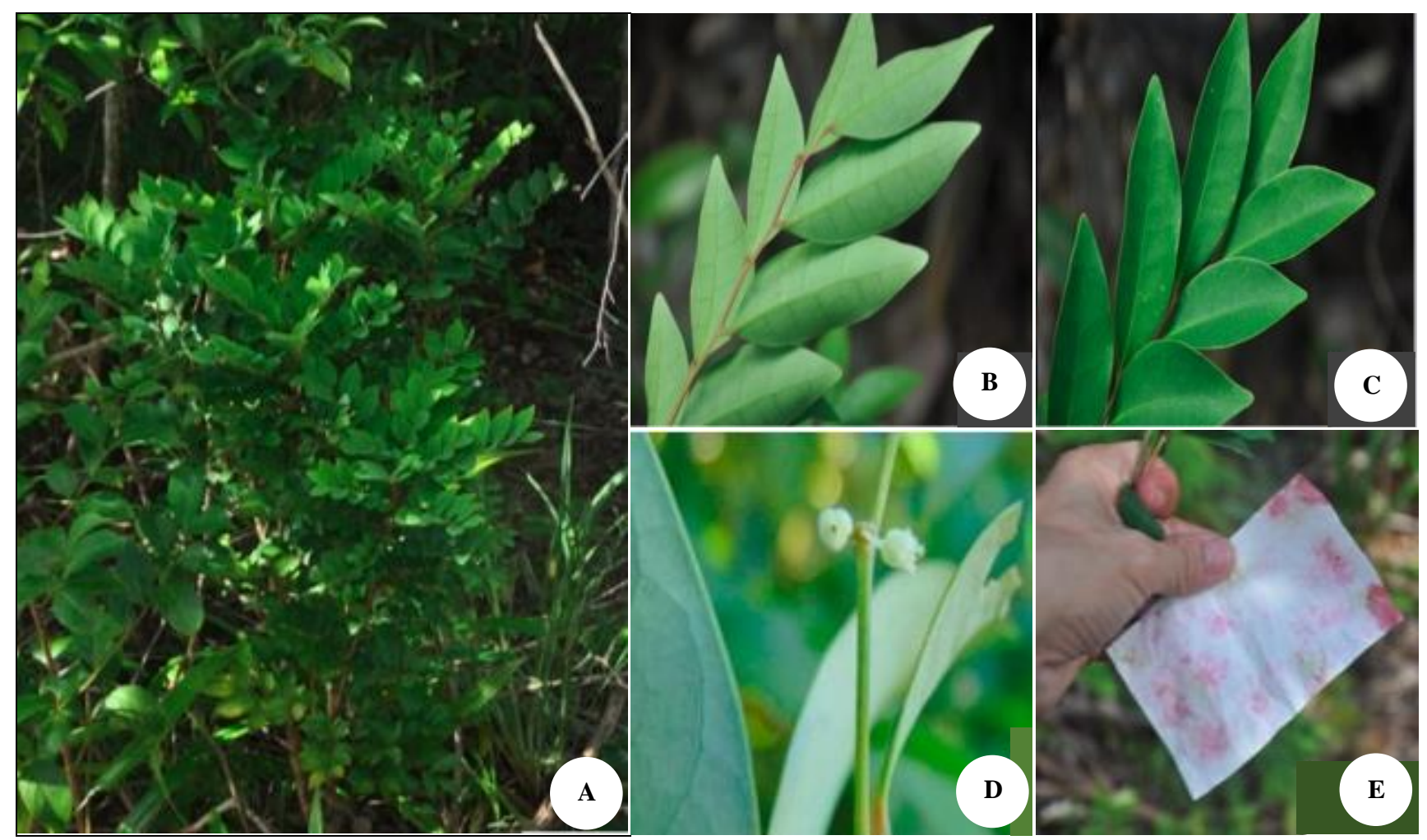

Figure 2. Phyllanthus securinegoides Merr. A. Growth habit type at locality, B. Leaves abaxial surface, C. Leaves adaxial surface, D. Twig with flower, E. Nickel hyperaccumulator by a field test using filter paper impregnated with $1 \%$ dimethylglyoxime dissolved in 95\% ethanol. Photos were taken by R.B. Romeroso and D. N. Tandang

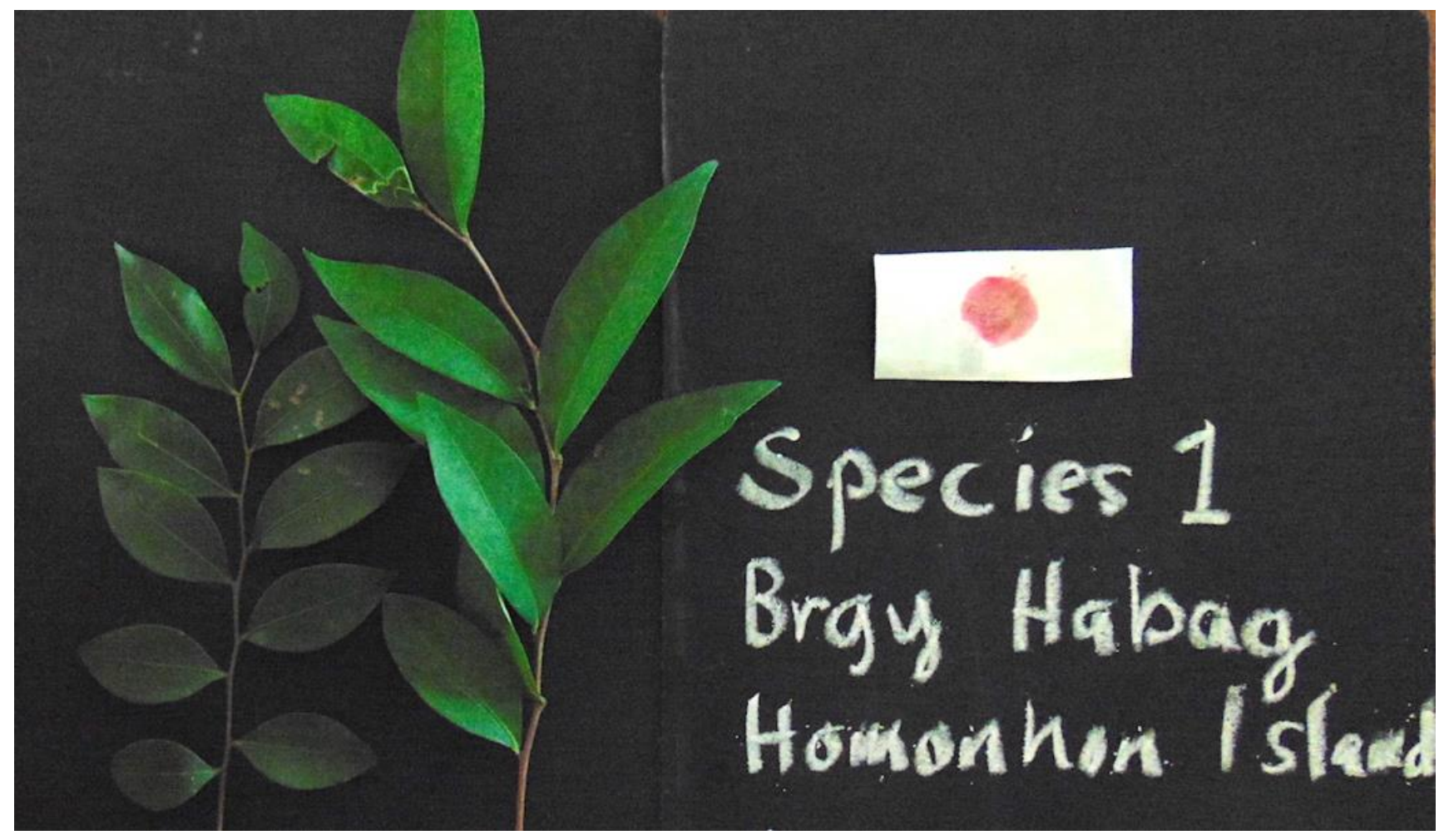

Figure 3. Phyllanthus securinegoides Merr., shown as a nickel hyperaccumulator by a field test using filter paper impregnated with $1 \%$ dimethylglyoxime dissolved in $95 \%$ ethanol. Photograph by R.B. Romeroso and I.A. Navarrete 

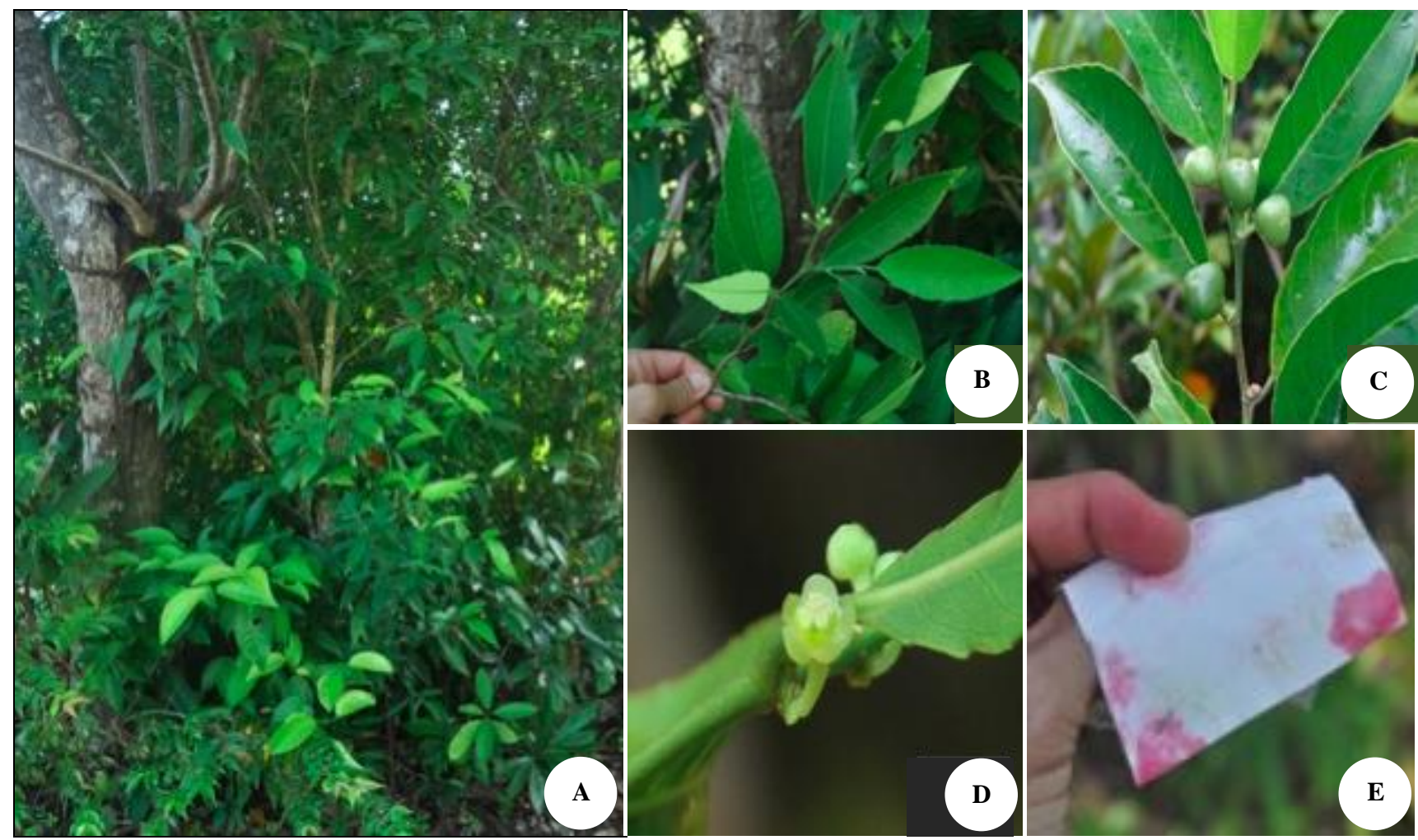

Figure 4. Rinorea niccolifera Fernando. A. Growth habit at type locality, B. Twig with young fruit and flower buds, C. Twig with fruits D. Twig with flower, E. Nickel hyperaccumulator by a field test using filter paper impregnated with $1 \%$ dimethylglyoxime dissolved in 95\% ethanol. Photos were taken by R.B. Romeroso and D.N. Tandang.

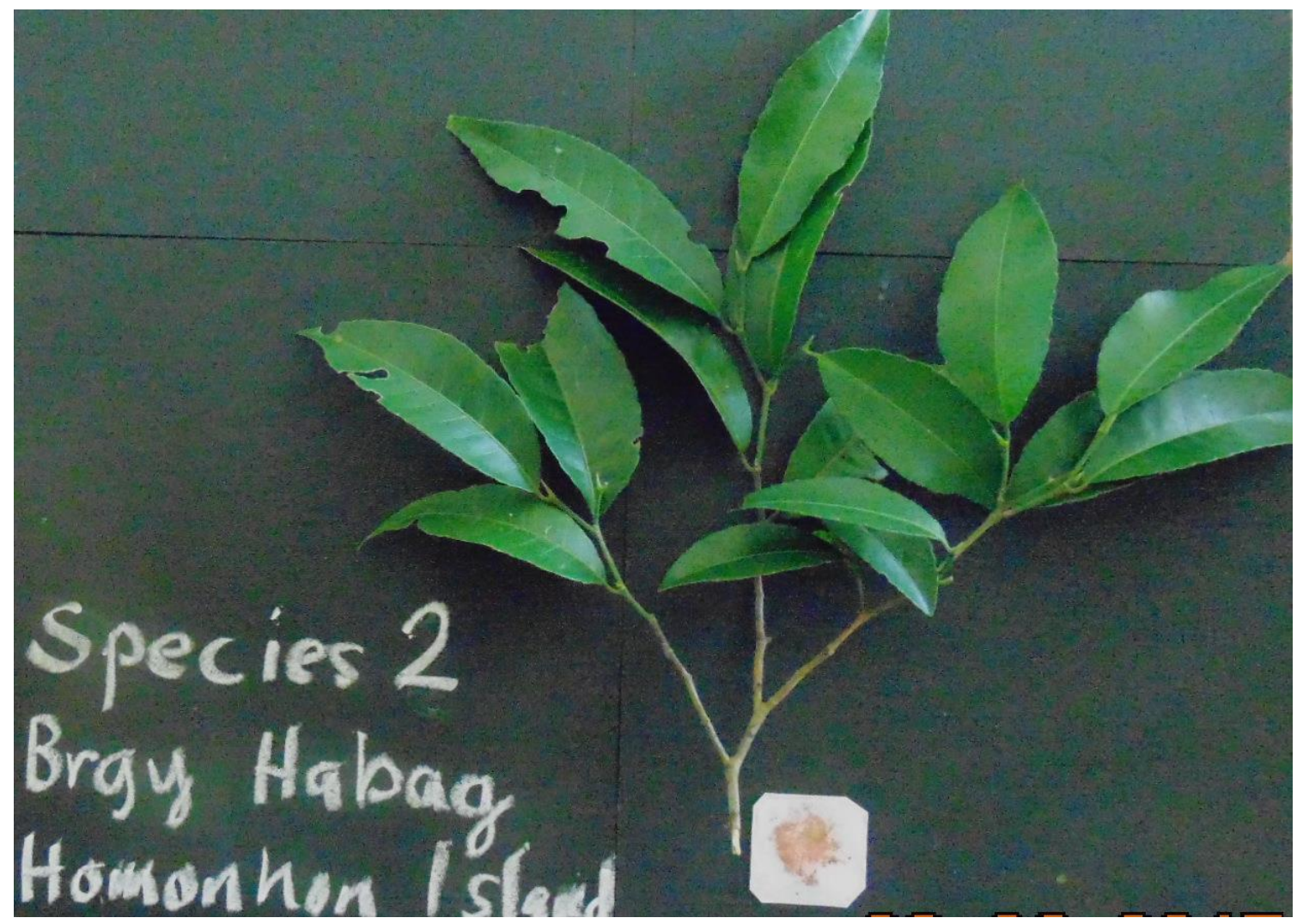

Figure 5. Rinorea niccolifera Fernando, shown as a nickel hyperaccumulator by a field test using filter paper impregnated with $1 \%$ dimethylglyoxime dissolved in $95 \%$ ethanol. Photograph by R.B. Romeroso and I.A. Navarrete 
In conclusion mining activities in the island started decades ago due to the abundance of heavy metals, specifically chromium and nickel ore. Metallophytes are plants grown naturally on metal-rich soils that are able to accumulate heavy metal in their biomass with no adverse effect on its physiological processes or without showing phytotoxicity (Baker and Brooks 1989). This study reported new distributional records of metallophyte species in Homonhon Island, Philippines. The presence of these metallophytes in the area has potential implications in the ecological restoration of heavy metal-contaminated areas as well as for policy making conservation of these native metallophytes for phytoremediation. Hence, there is a need to conduct more studies on metallophytes in the Philippines to know the distribution of these species since these species have the potentials to be used for rehabilitation and phytoremediation of contaminated areas.

\section{ACKNOWLEDGEMENTS}

The authors would like to acknowledge Mayor Christopher Sheen Gonzales of Guiuan, Eastern Samar for the prior informed consent; the Department of Environment and Natural Resources (DENR) Tacloban City, for the gratuitous permit in allowing us to perform the study; the Community Environment and Natural Resources (CENRO), Borongan City Eastern Samar for the local transport permit 11-002-16; and the barangay captains and residents of Homonhon Island for their valuable support and participation. The first author would like to acknowledge the Department of Science and Technology, Accelerated Science and Technology Human Resource Development Program (DOST-ASTHRDP) for the provision of the Ph.D. scholarship and the Forest Foundation of the Philippines (FFP) for the project grant.

\section{REFERENCES}

Abulencia MFB. 2013. Characterization of Soils Derived from Ultramafic Rocks in Homonhon Island, Philippines. [Thesis]. Visayas State University, Baybay City, Leyte, Philippines.

Amoroso VB. 2012. Plant Diversity in Two Philippine Long-Term Ecological Research Sites. Springer, Tokyo.

Aribal LG, Marin RA, Miras NP. 2016. The metallophytes in the ultramafic soil of Mt. Kiamo in Malaybalay, Bukidnon, Philipp J Biodiv Environ Sci. 8: 142-150.

Ata JP, Luna AC, Tinio CE, Quimado MO, Maldia LS, Abasolo WP, Fernando ES. 2016. Rapid Assessment of Plant Diversity in Ultramafic Soil Environments in Zambales and Surigao del Norte, Philippines. Asian J Biodiv 7: 1-16.

Baker AM, Brooks RR. 1989. Terrestrial higher plants which hyper accumulate metallic elements - A review of their distribution, ecology and phytochemistry. Biorecovery 1: 81-126.

Brown R, Silver C, Oliveros C, Esselstyn J, Diesmos A, Hosner P, Alcala A. 2013. Evolutionary processes of diversification in a model island archipelago. Ann Rev Ecol Evol Syst 44: 411-435.

Castells JC. 2010. A Review: Conservation of oceanic island floras: Present and future global challenges. Perspect Plant Ecol Evol Syst 12: 107-129.

Chafjiri LNS, Abkenar TK, Navroudi IH, Pourbabaei H. 2016. Distribution of plant species and their relation to soil properties in protected and degraded stands of Quercus macranthera in Northern Iran. Ecologia Balkanica 8: 53-63.

Fernando ES, Quimado MO, Trinidad LC. 2013. The potential use of indigenous nickel hyperaccumulators for small-scale mining in the Philippines. J Degraded Mining Lands Manag 1: 21-26.

Fernando ES, Quimado MO, Doronila AI. 2014. Rinorea niccolifera (Violaceae), a new species, nickel-hyperaccumulating species from Luzon Island, Philippines. Phytokeys 13: 1-13.

Kicinska A, Kosowska AG. 2016. Long-term changes of metal contents in two metallophyte species (Olkusz area of $\mathrm{Zn}-\mathrm{Pb}$ ores, Poland). Environ Monit Assess 188: 339. DOI: 10.1007/s10661-016-5330-3.

Merrill ED. 1912. Notes on Philippine Euphorbiaceae. Philipp J Sci Bot 7: 379-410.

Pielser P, Barcelona J, Nickrent D. 2011. Co's Digital Flora of the Philippines. https: //www.philippineplants.org/ [6 September 2019]

Quimado MO, Fernando ES, Trinidad LC. 2015. Nickelhyperaccumulating species of Phyllanthus (Phyllanthaceae) from the Philippines. Austr J Bot 63: 103-110.

Replan EL, Malaki ABB. 2017. Floral diversity and habitat assessment of Canbantug Forest, Argao, Central Visayas, Cebu, Philippines. Intl J Sci Eng Res 8: 775-780.

Whiting SN. 2004. Research priorities for conservation of metallophyte biodiversity and their potential for restoration and site remediation. Restor Ecol 12: 106-116. 